\title{
The right to leisure and the city: the experience of a social tourism project in Brazil
}

\author{
Bernardo Lazary Cheibub* Flávia Barros Guimarães** \\ Mariane Giselle da Costa*** \\ Federal Fluminense University (Brasil)
}

\begin{abstract}
An extension project has provided tourist experiences for students/staff of Fluminense Federal University who have some limitations. This article is the result of an investigation of how the tours influenced the daily life of the people who participated. It is an exploratory qualitative study based on semi-structured interviews with the tourists who visited some tourist spots. The relevance of the study is its demonstration that access to touristic leisure can bring physical, psychic and emotional benefits, such as different perception of places visited previously, change of habits, and possibility of experiencing contemplative moments to escape from everyday problems. The results show that access to the different tourist attractions and cultural facilities brought different contributions and perspectives. Subjects to the stress of the academic routine, the practice of touristic leisure helps them to ameliorate emotional/physical exhaustion and the sense of belonging, in relation to the university and the places visited.
\end{abstract}

Keywords: Social tourism; Leisure; Cultural citizenship; The right to the city; Social rights.

El derecho al ocio y a la ciudad: la experiencia de un proyecto de turismo social en Brasil

Resumen: Un proyecto de extensión ha proporcionado experiencias turísticas para estudiantes/empleados universitarios de la Universidad Federal Fluminense que tienen algunas limitaciones. Este artículo es el resultado de una investigación sobre cómo los recorridos ofrecidos por el proyecto influyeron en la vida cotidiana de las personas que participaron. Esta es una investigación cualitativa exploratoria, basada en entrevistas semiestructuradas con turistas que visitaron algunos lugares turísticos. La relevancia del estudio es demostrar que el acceso al ocio turístico puede traer beneficios físicos, psicológicos y emocionales, así como diferentes percepciones de lugares visitados anteriormente, cambios en los hábitos y la posibilidad de experimentar momentos contemplativos para escapar de los problemas cotidianos. Los resultados muestran que el acceso a las diferentes atracciones turísticas e instalaciones culturales de los lugares visitados aportó diferentes contribuciones y perspectivas para estas personas. Sujeto al estrés de la rutina académica, la práctica del ocio turístico les ayuda a mejorar el agotamiento emocional / físico y el sentimiento de pertenencia, en relación con la universidad y los espacios visitados.

Palabras Clave: Turismo social; Ócio; Ciudadanía cultural; El derecho a la ciudad; Derechos sociales.

\section{Introduction}

This article describes the main results of an investigation of the possible benefits for the individuals who participated in the touristic experiences promoted by the research and extension project called UFF Social Tourism at Fluminense Federal University (UFF), with regards to the debate about the rights to leisure and the city.

The project was conceived in 2013, after a request by the university's Office for Full Attention to Health and Quality of Life (subordinated to the Personnel Management Department), addressed to a

* Federal Fluminense University (Brasil); E-mail: bernardocheibub@id.uff.br

** Federal Fluminense University (Brasil); E-mail: flaviaguimaraes@id.uff.br

*** Federal Fluminense University (Brasil); E-mail: marianegisellec@gmail.com 
professor of the School of Tourism and Hospitality, to choose two of his undergraduate students to work with that office in return for scholarships. This gave rise to the concept that would later result in the development of an extension activity connected to social tourism, aimed at promoting activities for the university's academic community.

In 2015, the project became official under the name "Social Tourism for UFF Students and Employees", providing low-cost tourism experiences to students and staff of the University who faced difficulties in accessing tourism activities due to social, economic, spatial and cultural issues, among others. Since 2017, the Project's activities have expanded beyond the university by forming partnerships with: Centro Pop (Specialized Reference Center for the Homeless Population, a public unit located in Niterói, UFF's hometown, in the metropolitan region of Rio de Janeiro); Coexistence and strengthening bonds service group for the elderly of CRAS Barreto (the Social Work Reference Center in the district of Barreto in Niterói); The Center for Coexistence and Culture of the Niterói Mental Health Program; A nongovernmental organization called Preventório Jiu-Jitsu, for children (in a favela, also in Niterói); An institution responsible for children abandoned called Lisaura Ruas; and an organized group of UFF mothers. By means of these agreements, free leisure and cultural activities have been offered to the homeless population, elderly people with a vulnerable social and economic status, people with mental disorders and poor families and children, who are serviced by the respective entities. In 2017, as a result of this expansion, the project's name was changed to UFF Social Tourism.

In practices related to students and workers, day trips are conducted four times a year and destinations have so far included tourist attractions in the cities of Niterói, Rio de Janeiro, Petrópolis, Maricá, Cabo Frio and Itatiaia, all in the state of Rio de Janeiro. Due to the large number of people registered, 300 per trip on average, participants are chosen in a selective process that aims to prioritize students and employees who are in a context of social and economic vulnerability. As of now (2020), about 500 individuals have taken part in 15 excursions.

In addition to bringing the tourism experience closer to people who have less access to it, the purpose of the project is to provide the participants with welfare and interactions with an environment that is different from their usual one, stimulating the integration and socialization outside their study or work routine. Leisure can be seen as promoting health, well-being and quality of life, by providing physical and mental refreshment. Although the practice of tourism as leisure is a transforming agent for those who can access it, only a few studies have presented an in-depth discussion of its possible benefits (McCabe, 2009).

In 2017, the project was connected to UFF's academic development program and started to receive scholarship students in the program, who have been added to the investigation summarized here. This work is the product of a study by two scholarship students (from undergraduate courses in Tourism and Social Work), who took part in the program, under the responsibility of the Student Affairs Office, according to which the program aims to integrate actions for social and economic support, seeking to aid students who have social and economic vulnerabilities in completing their undergraduate studies, connecting extension actions to their scientific research. In the second semester of 2017, we analyzed the activities of the UFF Social Tourism with the goal of reflecting on the possible contributions of the touristic experiences to the lives of the participants, by means of a semi-structured interview script comprised of eight open questions directed to participants in the project. A bibliographic review involving relevant authors who have studied the themes social tourism, right to leisure and right to the city contributed to the preparation of the field research. Furthermore, it generated a better understanding of the results, and is subsequently examined and presented in this paper based on the main theories of the authors considered.

Once the script was prepared, we contacted approximately 300 people - everyone who had benefited up to that moment - and conducted 30 in-person interviews with those who accepted the invitation (all with audio recording authorized by the respondents by signing the informed consent form). From that sample, twenty-two respondents were female and eight were male, with ages varying from 19 to 64 years. Seven respondents declared income less than the minimum monthly salary, twelve received between 1 and 2 times the minimum, two between 2 and 6 times the minimum, one more than 6 times the minimum, and eight chose not to disclose their income. Regarding destinations, 19 had taken part in excursions in Petrópolis, three in Rio, four in Niterói, three in Rio and Niterói, and finally one visited all three destinations. This Data were collected from the trip registration forms filled in by the participants.

The interviews followed the thematic oral history method, in which it is possible to give voice to people who are generally excluded and thus "reinsert them" in history. According to Le Vem et al., these interviews allow the respondents to become the protagonists of their own history by reflecting on the experiences and allowing them to question their experiences (cited in Alves, 2016: 4). In the words of Freitas: 
With thematic oral history, the interview has a thematic character and is conducted with a group of people, on a specific subject. This interview - which has the characteristic of testimony - does not necessarily cover the respondent's entire existence. In this way, the testimony can be more comprehensive, resulting in greater amounts of information, which allows comparisons, pointing out divergences, convergences and evidence of a collective memory, for example (2006: 21 - 22).

In oral history, the data processing technique works with what was actually said, and also with the place occupied in the set of relations in question.

Some bullet points were prepared to support the construction of the script, and the interpretation and selection of data obtained in the field research: the Social Tourism project offers free tours for groups at risk of social exclusion; tourist leisure could be a need, a privilege, a right, and/or a possibility; since certain places are public, they should be accessible by all inhabitants; and social tourism policies can bring benefits to people. The survey highlights built the path of this article, mixing field research with contexts, and when relevant, with the theoretical debate - in other words, a thematic-contextual guideline was designed, inserting the presented reality in a specific way through the interlocutors.

\section{Tourism: a privilege or a right?}

By generating multiple activities and experiences, tourism is one of the most relevant social phenomena in modern history. It involves an individual's temporary visit to locations outside of their normal surroundings (Banducci \& Barretto, 2001). However, most of the time tourism is considered and exercised only as an economic activity that generates revenue and jobs. One of the greatest challenges is to enable the equitable distribution of opportunities to access the activities involved in tourism, as a possibility for rest and enjoyment, clear aspects of leisure activities (Cheibub, 2014). From the perspective of social rights, we are discussing the consolidation of leisure as a public service, so that the population effectively appropriates it (Areias, 2011).

The materialization of social rights allows politically organized societies to reduce the excesses of inequality produced by capitalism, guaranteeing a minimum of well-being for all (Carvalho, 2007). We believe that social rights are a guarantee on the part of the State that its citizens have minimum conditions for survival, varying according to the stage of development of each society (Cheibub, 2015).

In Brazil, leisure is a social right protected by the 1988 Constitution in its Chapter III, Article 6, as follows: "All have the social rights, in the form of this Constitution, to education, health, work, habitation, leisure, safety, social security, protection of maternity and childhood, and assistance to the needy" (Brazil, 2013).

Access to various forms of leisure should not, therefore, configure any type of privilege; social tourism arises as a possibility of democratizing tourism and ensuring the right to leisure of individuals or groups that for economic, social, spatial, cultural and/or physical reasons have difficulties in accessing it (Cheibub, 2014). From this perspective, a natural question arises: How do the participants see their experiences in the Project, as a right or as a privilege?

From the interviews conducted, duality was observed between the idea of privilege and right in the respondents' answers. In summary, of the 30 interviewees, 10 considered leisure to be a privilege, 7 a right, 12 a privilege and right at the same time, and one participant stated that he did not classify it as either a right or a privilege. Many of them stressed that despite being a right, touristic leisure in practice is a privilege, a discretionary activity for few, since few people have access to it. Some (7) linked it to a privilege due to having been selected among many applicants, and also because the project is offered mostly to those who have some kind of connection to UFF. Of those who considered it a right, 3 (all employees of the institution) classified it because they believed it was a "debt" from the university as a return on the taxes paid by them that results in the provision of public services. As can be seen, the answers revealed that the conceptions of privilege and rights were mostly ambiguous and imprecise.

We highlight some excerpts that reflects most of the answers we received:

\footnotetext{
"It should be a right, but we see it as a privilege because not everyone has access to it. Many people do not have access to that privilege. In our current situation, many people are lacking [this]";

"It depends on the viewpoint. Right, everyone has a right: students, teachers, technicians, everyone has a right. Privilege [would be] you being drawn among 500 people who signed up and tried to fill the opening"; "It as a right because everyone has the right to come and go, [...] to walk. As a citizen [...] you have the right to do everything [...]. And It as a privilege because there are limited seats".
} 
It can be concluded that even if the individuals identify (touristic) leisure as a right, in practice, this opinion dissipates due to its restriction to a few groups. The right to leisure could be "read" by the population as contradictory. Depending on the option, it may seem available, but at the same time be hard to access and enjoy. In that sense, most participants highlighted that financial issues are one of the main determinants for having access to tourism. In the words of one participant:

It's all too expensive. I love traveling, but I can't do it as often as I'd like [...]. Maybe at most I can visit places that are free, where you can stay at someone's place, something like that. [...] If you have financial resources, you can make plans, organize, and think about accommodations, meals.

Of the universe of respondents, 25 indicated that one of the biggest obstacles that prevents them from enjoying tourist leisure is financial situation ${ }^{1}$. One of the respondents stressed that although some places offer reasonable prices, failures in the disclosure of more appealing information makes nearby tourist destinations seem inaccessible. Some participants (10) stated that the low availability of free time is a barrier that limits access, because the time employed in a tourist experience means forgoing resting time from their long work or study routines. They noted that tourism as leisure has contradictions: it is a right (as is the case of all leisure activities), but in practice is limited to certain groups that have access to information, availability of time and money.

Considering the social context in which they are inserted and the perception that leisure manifestations configure a privilege, it can be perceived that the access difficulties reported by the respondents are also related to the conditions in which the working class lives in Brazil.

I don't know if I could classify it as a right or a privilege in the current moment that we live. If it were at another time, if the question was a couple of years ago, I would say it is a right. [...] At a time of conservatism, it is complicated for us to demand something that may end up taking a scholarship from someone or some kind of resource.

This statement may indicate that, when rights considered by most of society as essential (education, health, work, habitation, safety, social security, assistance to the needy, etc.) are constantly threatened, other rights (also important, such as leisure and culture in their diverse practices) are seen as privileges. Pereira presents an interesting reflection on this issue:

[...] current social policies reduce the needs of the poor to the most miserable and humiliating condition of a physical, animal, beastly life, whose satisfaction only enables them to perform mechanical activities to survive. And the naturalization of this process makes many - including ruling politicians - believe that the poor have no need for leisure, for culture and particularly for autonomy to make choices, to feel responsible for themselves and to participate in the economic, political and social life within the context in which they live (2006, p. 72).

When paying attention to the issues connected to social tourism as a guaranteed right, reflections on the right to enjoy the city arise.

\section{The right to the city and cultural citizenship}

With the social science support, this work can generate a debate involving themes such as cultural democracy, social protagonism and the right to culture and leisure, especially in dialogue with some classic and contemporary social science authors regarding the theme of the right to the city.

In general, cities should be able to welcome and integrate their residents, ensuring social welfare supported by security, social integration, opportunities for work and income and diversified access to cultural assets; thus, people are able to develop feelings of identity, pride and citizenship (Matheus, 2002).

However, cities do not always manage to accomplish these roles as comprehensively as they should. A large part of the Brazilian working class lives far from the central region of cities and has less options of equipment and services for leisure, health, transport, culture, work, etc. In this configuration, the farther people live from large centers, the fewer are possibilities to access city spaces related to quality of life, thus denying full exercise of cultural citizenship. With regards to that, Farage, Da Silva Brito \& Pereira highlight:

Brazilian urbanization is marked by a deep social and spatial segregation, creating two different types of city in the same territory: one side concentrates the services and infrastructure required for a dignified life in the city (transport, lighting, sanitation, public safety, etc.), while in the suburbs millions of people live in highly precarious conditions in all the aforementioned aspects $(2015$, p. 11). 
Many of the respondents listed reasons for not being able to practice touristic leisure. They claimed not to have access to sights and cultural facilities in the city where they live or in nearby locations. As briefly explained in the previous section, 19 of the interviewees pointed out the cost of living as the greatest impediment to visiting new places, while 7 stated that the main obstacle is lack of time. Some participants also mentioned other obstacles: lack of opportunities, information and companionship; the issue of (i) mobility and the lack of accessibility (geographic-spatial distance, difficulty in accessing public transport and physical-architectural barriers); and security (fear of violence).

Social groups with greater purchasing power have easy access to the places to exercise full citizenship rights, while the other portion of the population is excluded, occupying areas that are largely abandoned by the public authorities, and become foreigners in their own city (Hardt and Hardt, 2015, cited in Sgarbossa, 2017).

The interviews conducted revealed that the participants identified their right to access tourist sights in their own city, but could not do so for economic reasons:

Sometimes it's all too expensive. Now we are at a time of crisis here in Brazil, everything is too expensive. Sometimes even places that are not that far become too expensive. I have been to Petrópolis before, and in other opportunities I gave up on going because the tickets are expensive. It's not that far [for it] to be so expensive. One has to pay for food, which is also a big expense. If you take all that [into account], the trip becomes as expensive as paying for tickets to another state. It's out of this world, because in Rio de Janeiro everything is too expensive, the cost of living [is high].

Another participant corroborated what the previous one said, that places close to their place of residence could "be a source of tourism" and that "people have a lot to explore and nobody explores due to lack of knowledge" and financial conditions. The city is often seen as a commodity, whose main purpose is generate profit, with high transport fares, giant events and real estate speculation, leaving the working class at the margins, unable to fully exercise their citizenship rights, especially to leisure.

This leads us to the report of one participant on the difficulty of accessing the iconic tourist attractions of the city in which he lives. The excerpt below stresses the view of leisure as a privilege and highlights that the city has become a commodity:

This is a privilege, because Niterói and Rio de Janeiro are very expensive cities to visit. I'm from São Paulo and I know very few sights around here. I have only visited places with free entrance. I have never been to the Museum of Tomorrow. [...] I have never been to several other places because I'd have to pay. Usually, if there's a free entrance day, it's on Tuesday, which is a workday. I think that is a big privilege nowadays because of the access issue.

Lefebvre (1967) argued that citizens are more objects than subjects in the social space, with the State and part of society not having and understanding of the importance of people being protagonists and builders of their own city. On the contrary, for the author, the State acts as an authority and planner, treating the resolution of any urban problems in an administrative, technical and scientific way, thus maintaining the alienation of citizens. The sociologist also stated that the State builds an urban scenario in which everyone must adapt to the way of life that existed before them, and constructed without their participation (Lefebvre, 1967).

Grinover (2006, p. 40) pointed out that the city should be a "[...] space not only for housing, but also for living and coexistence. It means living well, strolling pleasantly and safely, enjoying the services properly." In the current context, we observe that although attractive leisure equipment is located in many places within the city, most of these places become paid tourist attractions. This happens by privatizing the spaces, consequently preventing access by the lower class people due to the price of admission (Cheibub, 2019).

\section{Social tourism: impacts and contributions}

The research summarized here is relevant for the improvement of studies and analyses about social tourism, which is a growing practice in several countries of Europe and Latin America, where it is historically based on public and private leisure policies, offered by different institutions with different intentions and ideologies. The International Social Tourism Organization (ISTO, 2011, p.1) conceptualizes social tourism as: "the connections and phenomena related to the participation of people in the countries of destinations as well as of holidaymakers, of disadvantaged layers of society or those 
unable to participate in tourism, holidays and their advantages for whatever reason." Social tourism practices enable the poorest population to have access to tourist experiences even in their home city.

In Brazil, investigations that analyze the different practices of social tourism are scarce. According to Marcelo Vilela de Almeida (2016, p. 144), the subject has always been considered marginal in the scope of academic research: "In addition to the occasional involvement with the theme of some researchers and authors [...], the efforts of Almeida (2011) and Cheibub (2014) to undertake systematic and frequent studies on the topic stand out".

Minnaert, Maitland \& Miller (2012) pointed out that social tourism should be considered a right according to the "types" of societies. According to the authors, social tourism is seen as a right in societies where the richest support the poorest by means of paying taxes; thus, composing and structuring the less favored layers of society is a way to ensure access to certain government-provided rights and benefits. It is important to observe that in these societies, taxes are progressive, that is, the richest pay higher tax rates, so that wealth is redistributed by means of rights and benefits. The political principle that governs these nations is social democracy based on the effectiveness of social rights by means of public policies.

On the other hand, in neoliberal societies, social tourism is not deemed a right (Minnaert et al., 2012), since the main pillar in these societies is a minimal State, that is, a State where social policies are focused on people in extreme poverty. For the rest of the population, however, the same policies become services, so one must pay to enjoy them.

Social tourism can enable the personal development of those who practice it (Castro, 2016). Lima, Eusébio \& Varum (2011) reinforced this idea by contending that social tourism can bring benefits to families and collaborate with socialization and expansion of friendship networks. In this way, the excursions may provide new perspectives for those who take part in them, be it as a reflection on their own reality or by paying attention to the reality of the place they are visiting and its residents. When inhabitants move around, traveling to places they are not used to visiting, they can develop their feelings of belonging to these locations (Gastal, 2006). One participant clearly expressed this feeling, shared by all others 29 :

I think it opened my eyes to this: that you can get away from your reality a bit, get out of your routine while still being very close to home. Valuing and exchanging ideas. Exchanging ideas is very important. The Project provides a lot of this: that we can travel so close, that it starts from within, in our imagination and where we live. You don't have to go abroad.

This goes hand in hand with the reflection presented by Castro (2016) that common sense tends to make people believe it is not possible to have new experiences within one's own city, and that only by visiting "new" places can people be able to have genuine tourist experiences. The author (Castro, 2016, p. 126) states that: "[...] by revisiting a space that exists around them, within a different perspective and context, an individual can benefit from a new experience that may offer a lot more than the touristic activity itself".

These ideas are supported by this study, since the respondents clearly expressed this change in perspective. For one of the participants, the experience she had with social tourism made her start to see the local culture under a new light, and she started to dedicate more time to visit the sights, making them her own.

Another respondent (and more 5) highlighted the possibility of seeing a part of his routine in a different manner as a result of the excursion:

For example, I recall that the final part of our October excursion in Rio was at Campo de Santana [park]. I had been to Campo de Santana before, because I studied [nearby] at the UFRJ School of Law, but I'd never seen some of the things in there, and I didn't even know about some projects connected with Campo de Santana.

This leads to the understanding that the tourism can be experienced within people's city of residence and/or work, enabling them to see what they routinely see under a new light, whetting their curiosity. By leaving their homes to have new experiences in their own city, citizens can enjoying spaces that belong to them by right, setting aside any feelings of being outsiders or the sensation of not belong to that place (Eugênio, 2018). The benefits generated by touristic experiences within one's own city may be 
greater than those generated by visiting another place, since the individual already has a relationship with the local spaces and can develop a new, both simplistic and critical, view (Castro, 2016).

We can thus list the benefits of social tourism for visitors under three categories: physical and psychological; educational and evolutional; and social (Lima et al., 2011). Among those, we highlight the psychological benefits as the ones given greater emphasis by the participants in their interviews. According to them (6), the trip provided them with a relaxing moment amid their daily stress from academic life or familial and financial difficulties. This is evidenced by the comment of this participant:

So, last year was a very complicated year for me personally. My mother left her job and started on a new job, and we were kind of low on money. Last year was a rough year for us, and we didn't go anywhere. It was good to be able to leave that environment for a while. [...] The trip was in December, at the end of the semester, so it was really good. I could see I don't have to just stay at home. I don't have to just study. I can go out as well. And since I went with a friend, it was a really cool experience.

One can see in this comment that the touristic experience can be a tool to help individuals, at least momentarily, to focus less on their daily struggles and try to relax. This fits what Lima et al. (2011) classified as "physical and mental relaxation/evasion" and "escaping from daily stressors and pressures."

Another example of a psychological benefit arising out of the practice of social tourism was perceived by a participant who stated she found it very difficult to leave her house due to post-traumatic stress. However, during the trip, she felt safe and comfortable to enjoy the experiences. Finally, she reported that not feeling her habitual fear was a unique sensation. In her words:

Once I got home, I went through all this and I didn't worry about the place where I was; I wasn't worried about my things, that someone would come after me. So I think that was the main impact, because I saw there is a way of living where I'm not necessarily unsafe all the time. It was very unusual to come home and reflect on this issue of fear, of unsafety, of how other people live.

In addition to the reports of psychological contributions achieved, some participants (11) found that the trip enabled them to expand their friendship circles. For one of the respondents: "This is also a way to interact with people we don't know, because we keep very enclosed in our niche. I only have friends from my course. And thanks to this, we met a lot of people. So we made a circle of friends". Other participants saw the opportunity to share their experiences, inviting people in their social circle to take part in the activity:

I've told my brother that when we take our vacation we are going to check out these places we didn't know. To see other things, sides of history - we think [history] goes one way, and when you see something that was discovered there, you see that reality was different.

Social tourism can also provide other benefits to people, such as increasing self-esteem, improving family relationships, opening new horizons, etc. (Minnaert et al., 2012). In that sense, it is possible to cover a few issues related to the new points of view for the individuals' professional and personal lives.

We can illustrate this with the comments of a 62-year old participant who considered going back to her studies and taking a course in tourism and hospitality after participating in one of the trips, a possibility that had never crossed her mind before. Another case that can be highlighted occurred during one of the trips in the city of Rio de Janeiro, where one participant expressed her gratitude for being included and being able to bring her eleven-year old son. She emphasized that the child, who up until then had always felt bored when visiting museums, showed great interest in the places visited, which created a possibility for her to take him with her to other places in the future.

The comments exposed here evidence that social tourism can cause changes in the lives of those who practice it, because they gain a new perspective on spaces and experiences that were part of their routine until then. Additionally, they start to share this different point of view with their loved ones, (in)directly impacting their families and friends, who are interested in and curious about their reports.

Therefore, social tourism collaborates by establishing new habits among people of the lower social classes - who usually do not go to the places visited by the more privileged classes of the Brazilian population - generating better quality of life and renewing their feelings of belonging and identity. 


\section{Conclusions}

The binomial "social exclusion" is present in several studies dealing with poverty and inequalities. Unlike the pattern of the academic production in the social sciences so far, tourism, leisure and urban public spaces need to be considered in an articulated way, taking into account inequalities of access and opportunities. Despite being a constitutional right in Brazil, leisure does not receive great attention from the public authorities, who neglect groups with fewer opportunities. Leisure activities are usually seen as ways to generate more revenue. The population has very limited leisure options. Most people do not have full access to exercise their rights in the city and live far from tourist spots in (large) urban centers.

Considering the difficulty of accessing leisure manifestations and the tourism market, social tourism is an alternative that goes against commercial logic. The Social Tourism project at UFF is based on a proposal to enable experiencing tourism by students and employees of Fluminense Federal University who are prevented from or have few chances to have those experiences, due to socioeconomic, symbolic-cultural and/or physical-spatial issues, among others.

The interviews revealed that the duality between the ideas of privilege and right are paradoxical and complex in the respondents' opinions. It was possible to understand that some leisure activities are rarely understood as a right, even if guaranteed by the Constitution. As it is considered a discretionary activity for some people (compared to other more routine forms of leisure that happen much more frequently), the touristic experience - even within the city itself - is perceived as a privilege, which is strengthened by the existence of different barriers (especially financial), and the lack of transparency in the method for selecting applicants used by the Project. In addition, the notion of loss of rights - civil, social and labor -, which increased in 2016 through government reforms and neoliberal and conservative policies, also affected the perception of touristic leisure as a social right.

The theoretical debate and the study conducted with the participants of the trips organized by the Project revealed that social tourism can provide several benefits for the lives of those who practice it and also expand their conviviality circles. These benefits are reflected in the better quality of life achieved through democratizing city spaces, providing cultural accessibility and social interactions, preserving memories and creating new habits, feelings of belonging and acknowledging citizenship rights.

This study also reveals the importance of actions to democratize access to leisure - particularly tourism - and to enable all groups to fully enjoy their right to the city and its spaces. It is essential for the government in its various spheres - municipal, state and/or federal - to understand its role and act concretely to make cities fully accessible to users by protecting their rights and providing information/ education.

\section{Acknowledgements}

We are grateful for financial support from FAPERJ (Research Support Foundation of the State of Rio de Janeiro), Brazil, which provided funding for the translate services.

\section{References}

Almeida, M. V. de. 2016. Social tourism: Reflections and practices in Brazil. Journal of Tourism and Development, 26, 141-154.

Alves, M. C. S. O. 2016. A Importância da História Oral como Metodologia de Pesquisa. In: IV Semana de História do Pontal / III Encontro de Ensino de História: 2016, Ituiutaba-MG.

Areias, K. T. V. 2011. Direito social ao lazer no Brasil: análise das contribuições da produção acadêmica difundida no campo da educação física, da Constituição de 1988 aos dias atuais. Dissertação de (Mestrado em Educação Física), - Centro de Educação Física e Desportos. Universidade Federal do Espírito Santo, Vitória.

Banducci, Á.; \& Barretto, M. 2001. Turismo e identidade local: uma visão antropológica. Campinas, São Paulo/Brazil: Papirus.

Brazil 2013. Constituição da República Federativa do Brasil. Brasília, Distrito Federal/Brazil.

Carvalho, J. M. 2007. Cidadania no Brasil: o longo caminho. 9ª ed. Rio de

Janeiro/Brazil: Civilização Brasileira. 
Castro, M. G. 2016. Rosa dos Ventos: turismo social para crianças e sua relação com o turismo pedagógico. Bachelor's thesis. Federal Fluminense University, Niterói, Rio de Janeiro/Brazil.

Cheibub, B. L. 2014. A história do 'turismo social'no Serviço Social do Comércio-SP. Doctoral dissertation. Getulio Vargas Foundation, Rio de Janeiro, RJ/Brazil.

Cheibub, B. L. 2015. As contribuições da produção científica para o entendimento do lazer como direito social. In Gomes, C.L.; \& Isayama, H. F. (Eds.). O direito social ao lazer no Brasil (pp. 201-227). Campinas, São Paulo/Brazil: Autores Associados Ltda.

Cheibub, B. L. 2019. Turismo social e mediações: problematizando um projeto de extensão da Universidade Federal Fluminense. In Gomes, C. L.; Debortolli, J. A. O.; Silva, L. P. da. (Org.). Lazer, Práticas Sociais e Mediação Cultural. (pp. 219-235). Campinas, São Paulo/Brazil: Autores Associados Ltda.

Eugenio, J. O. 2018. A experiência turística da População em Situação de Rua da cidade de Niterói-RJ: Horizontes possíveis para o Turismo Social. MSc thesis. Federal Fluminense University, Niterói, Rio de Janeiro, Brazil.

Farage, E. J.; Da Silva Brito, F. M.; \& Pereira, G. S. 2015. Movimentos Sociais urbanos e o direito à cidade: a experiência do MTST na conquista e ampliação da política pública de direito à moradia. Proceedings of Encontro Internacional e Nacional de Política Social, Vitória, Espírito Santo, Brazil.

Freitas, S. M. de. 2006. História Oral: possibilidades e procedimentos. São Paulo: Associação Editorial Humanitas.

Gastal, S. 2006. Turista Cidadão: uma contribuição ao estudo da Cidadania no Brasil. Proceedings of XXIX Congresso Brasileiro de Ciências da Comunicação-UnB-Intercom-Sociedade Brasileira de

Estudos Interdisciplinares da Comunicação. Brasília, Distrito Federal, Brazil.

Grinover, L. 2006. A hospitalidade urbana: acessibilidade, legibilidade e identidade. Revista Hospitalidade, 3 (2), 29-50.

ISTO. 2011. The social and economic benefits of social tourism. Social tourism enquiry; Submission of International Social Tourism Organization: available at: http://nationbuilder.s3.amazonaws. com/appgonsocialtourism/pages/23/attachments/original/ ISTO_-_Inquiry_Social_Tourism.ISTO. pdf?1314889615 [cit. 20-06-2020]

Lefebvre, H. 1967. Metafilosofia. Rio de Janeiro: Martins Fontes.

Lima, J.; Eusébio, C.; \& Varum, C.A. 2011. O combate à exclusão social através de Programas de Turismo Social para famílias economicamente carenciadas. Tourism \& Management Studies, 639-653.

Matheus, Z.M. 2002. A idéia de uma cidade hospitaleira. In Dias, C.M.M. (Ed.) Hospitalidade: reflexões e perspectivas (pp. 34-45). Barueri, São Paulo/Brazil: Manole.

McCabe, S. 2009. Who needs a holiday? Evaluating social tourism. Annals of Tourism Research, 36 (4), 667-688.

Minnaert, L.; Maitland, R.; \& Miller, G. 2012. Social Tourism: perspectives and potential. Oxon / U.K: Routledge.

Pereira, P.A. 2006. Políticas públicas e necessidades humanas com enfoque no gênero. Sociedade em Debate, 12(1), 67-86.

Sgarbossa, G.K. 2017. O papel dos espaços públicos centrais para o desenvolvimento urbano sustentável. Revista TechnoEng, 57-71.

\section{Notes}

1 Several participants pointed out more than one obstacle.

Recibido:

$24 / 04 / 2020$

Reenviado:

$23 / 06 / 2020$

Aceptado:

$31 / 05 / 2021$

Sometido a evaluación por pares anónimos 